Article

\title{
Design of Bioinspired Emulsified Composite European Eel Gelatin and Protein Isolate-Based Food Packaging Film: Thermal, Microstructural, Mechanical, and Biological Features
}

\author{
Wafa Taktak ${ }^{1, *}$, Hela Kchaou ${ }^{1}$, Marwa Hamdi ${ }^{1}$, Suming Li ${ }^{2} \mathbb{D}$, Moncef Nasri ${ }^{1}$, \\ Maha Karra-Chaâbouni ${ }^{1}$ and Rim Nasri ${ }^{1,3}$ \\ 1 Laboratory of Enzyme Engineering and Microbiology, National Engineering School of Sfax, \\ University of Sfax, Sfax B.P. 1173-3038, Tunisia; hela.kchaou.enis@gmail.com (H.K.); \\ marwahamdi50@yahoo.fr (M.H.); mon_nasri@yahoo.fr (M.N.); \\ Maha.ChaabouniKarra@ipeis.rnu.tn (M.K.-C.); ryma47@hotmail.fr (R.N.) \\ 2 European Institute of Membranes, UMR CNRS 5635, University of Montpellier, Place Eugene Bataillon, \\ 34095 Montpellier CEDEX 5, France; suming.li@umontpellier.fr \\ 3 Higher Institute of Biotechnology of Monastir, University of Monastir, Rue Taher Haddad, \\ Monastir 5000, Tunisia \\ * Correspondence: wafa.taktak@gmail.com; Tel.: +216-54144640
}

Received: 2 December 2019; Accepted: 27 December 2019; Published: 30 December 2019

\begin{abstract}
The study focused on the elaboration and the characterization of blend biofilms based on European eel skin gelatin (ESG) and protein isolate (EPI) and the assessment of European oil (EO) incorporation effect on their properties. Data displayed that the incorporation of EPI and EO to the gelatin formulation decreased the lightness and yellowness of composite and emulsified films, respectively, compared to ESG film. Moreover, ESG films exhibited improved mechanical properties than EPI films. FTIR analysis, all incorporated films with EO at the ratio 1:4 (oil/polymer) revealed similar characteristic bands as in free-oil films. Further, the SEM images of 100\% ESG and 100\% EPI films showed a smooth and homogenous structure, whereas the cross-section of blend film (at a ratio 50:50) displayed a rougher microstructure. In addition, emulsified film ESG100 revealed a smooth and homogeneous microstructure compared to that prepared using EPI/ESG 50/50 ratio. Furthermore, EPI or EO addition into the ESG matrix enhanced the blend films antioxidant activities.
\end{abstract}

Keywords: protein isolate; gelatin; blend films; antioxidant properties

\section{Introduction}

In order to reduce environmental pollution and to conserve fuel reserves, the biodegradable packaging based on safe biopolymers has been investigated in many researches [1]. Films based on eco-friendly biopolymer displayed advantageous properties compared to the traditional plastics, favoring their potential application, mainly their biocompatibility, non-toxicity, availability, and biodegradability [2]. Furthermore, biopolymer-based films behave as selective barriers to oxygen diffusion, lipid oxidation, moisture transfer, and loss of volatile aroma compounds which improve food shelf-life and quality [3].

Various biopolymers, such as proteins, polysaccharides, and lipids, could be used to produce biodegradable films [4-6]. Fish gelatin and protein isolate have been previously used for developing bio-films owing to their availability and interesting film-forming capacities $[7,8]$. Fish protein isolate extracted by alkaline solubilization could be a potential alternative for films properties enhancement [9]. 
The interactions between protein chains via disulfide (S-S) covalent bonding, electrostatic forces, hydrogen bonding, and hydrophobic bonding favored the appropriate mechanical characteristics properties of protein isolate-based films [10]. Nonetheless, protein isolate-based films are, to a variable extent, rigid, attributed to the presence of strong covalent bonding, particularly disulfide bonds [11]. Protein isolate may be combined with other compatible polymers as an alternative to improve the thermo-mechanical properties of resulting films. Mainly, combining biopolymers with the most desirable characteristics of each component are anticipated for developing materials with exceptional properties [12]. Therefore, blending gelatin with protein isolate could solve the problem of brittleness and improve mechanical properties of protein isolate-based films.

Lipids could advantageously be mixed with above-cited polymers to form dried emulsions or bilayer films [13] able to protect foods against lipid oxidation, a serious problem that leads to the loss of products' shelf-life [14]. Indeed, due to the hydrophobic nature, the incorporation of oils in the formulation of films improved films water barrier property [15]. Thus, emulsified films with a potential water barrier ability are requested for the development of innovative foods processed and the extension of the shelf life of food [13]. In our previous studies, protein isolate (EPI) was extracted by the shifting-pH technique from European eel fish muscle and was applied for the preparation fish protein gels [16] and microcapsules [17].

Therefore, the present research aimed to evaluate the influence of European eel gelatin and protein isolate combination on the functional and antioxidant properties of blend films and the assessment of the effect of European eel oil incorporation on the of the film properties.

\section{Materials and Methods}

\subsection{Preparation of European Eel Protein Isolate}

The protein isolate (EPI) was extracted from European eel muscle by the $\mathrm{pH}$-shifting method according to the method previously described by Taktak et al. [16].

\subsection{Preparation of European Eel Skin Gelatin}

The skin was separated from muscle and viscera, rinsed with distilled water to remove salts and other contaminants. Gelatin was extracted from European eel skin as previously described by Jridi et al. [18].

\subsection{Preparation of European Eel Oil}

European eel oil (EO) was extracted from the upper layer, obtained in the first step of $\mathrm{pH}$-shifting process, reported by Folch et al. [19] and the fatty acids composition was determined using gas chromatography (GC) analysis as previously described in our study [17].

\subsection{Preparation of EPI/ESG Blend Films}

To prepare film-forming solutions, ESG and EPI powders were dissolved separately in distilled water to achieve final concentration of $4 \%$ and $2 \%(w / v)$, respectively. The solubilization of ESG was carried out at $40{ }^{\circ} \mathrm{C}$ for $30 \mathrm{~min}$. The optimal dispersion of EPI solution was obtained at $\mathrm{pH} 10.0$ according to a previous study (Taktak et al., 2018). Then, ESG and EPI film-forming solutions were mixed gently at different EPI/ESG mass ratios (0/100, 25/75, 50/50, 75/25, and 100/0 (w/w)) at room temperature $\left(25^{\circ} \mathrm{C}\right)$ for $15 \mathrm{~min}$. Glycerol was separately added as plasticizer to the ESG and EPI solutions at a level of $10 \%$ of total protein content ( $w / w$ polymer dry matter). The obtained films were named, respectively, ESG 100, EPI 25/ESG 75, EPI 50/ESG 50, EPI 75/ESG 25, and EPI 100.

Emulsified films (EF), prepared with the addition of EO, were noted EF-EPI 0/ESG 100, EF-EPI 25/ESG 75, and EF-EPI 50/ESG 50. Indeed, EO was added at a mass ratio of $1 / 4$ ( $w / w$ polymer) after glycerol addition. Finally, a volume of $25 \mathrm{~mL}$ of each formulation was casted into plastic Petri dishes $\left(13.5 \mathrm{~cm}\right.$ diameter), and dried, peeled off from the surface and equilibrated at $25^{\circ} \mathrm{C}$ and $50 \% \mathrm{RH}$. 


\subsection{Physical Characterizations of the Films}

\subsubsection{Moisture Content and Water Solubility}

Water solubility (WS) of films was carried out referred to the method of Gennadios et al., [20]. Moisture content (MC) of the films was resolved by drying $100 \mathrm{mg}$ of film samples at $105{ }^{\circ} \mathrm{C}$ in an oven until constant weight was reached. The moisture content of films is expressed as grams of moisture/100 g film.

\subsubsection{Color and Ultraviolet-Visible Spectroscopy (UV-Vis)}

A colorimeter (Chroma Meter CR-400; CIE, Konica Minolta, Osaka, Japan) was used to determine the color of blend films that was expressed as $L$ (lightness/brightness), a (redness/greenness) and $b$ (yellowness/blueness) values. To calibrate the chromameter, white standard color plate $(Y=94.1, x=$ $0.3134, y=0.3194)$ was used. The total color difference $(\Delta E)$ was calculated referring to the EPI film as follows:

$$
\Delta E=\left[(\Delta L)^{2}+(\Delta a)^{2}+(\Delta b)^{2}\right]^{1 / 2}
$$

where $\Delta L, \Delta a$ and $\Delta b$ are the differences between the color parameters of blend films and $100 \%$ EPI-based film.

UV-Visible spectrophotometer (SAFAS, UV mc, Monaco, France) was used in order to determine the UV-visible barrier properties of films in the wavelength range from 200 to $800 \mathrm{~nm}$. For this, films were cut into rectangle $(1 \mathrm{~cm} \times 3 \mathrm{~cm})$ and placed in the test cell. An empty test cell was used as a reference.

\subsubsection{Fourier Transform Infrared Spectroscopy (FTIR)}

The FTIR profiles of samples were recording using a spectrometer (Agilent Technologies, Carry 630 series, Santa Clara, CA, USA) equipped with an attenuated reflection accessory (ATR), in frequency range from 650 to $4000 \mathrm{~cm}^{-1}$. The OMNIC Spectra software (Thermo Fisher Scientific, Waltham, MA, USA) was used for the data analysis.

\subsubsection{Mechanical Properties of Composite Films}

The rheometer apparatus (Physica MCR, Anton Paar, GmbH, Les Ulis, France) equipped with a mechanical property measuring geometry were used for to elaborate the mechanical properties of films. Then, thickness of blend film $(1.0 \mathrm{~cm} \times 4.5 \mathrm{~cm})$ was determined in the controlled temperature $25{ }^{\circ} \mathrm{C}$ and $50 \% \mathrm{RH}$ for two weeks. The films retained in the extension grips, were exposed to a uniaxial tensile test, with a deformation rate of $5 \mathrm{~mm} / \mathrm{min}$ until breaking, based on the ISO standard (ISO 527-3:1995 [21]). Rheoplus software was used to estimate the mechanical properties (Tensile strength (TS) and elongation at break (EAB)). Average values from at least six measurements were reported.

\subsubsection{Thermal Properties of Composite Films}

The glass transition temperature $(\mathrm{Tg})$ of the macromolecular materials was determined using differential Scanning Calorimeter (DSC) (Modulated DSC Q20, TA Instruments, Network Analyzers, $\mathrm{NJ}$, USA) from 0 to $225^{\circ} \mathrm{C}$ at a rate of $10^{\circ} \mathrm{C} / \mathrm{min}$. After the precisely weight of films into aluminum pans and sealed, an empty capsule, which assists as an inert reference and the apparatus, was then calibrated using indium. Each pan was heated under a nitrogen flow rate of $50 \mathrm{~mL} / \mathrm{min}$. Finally, the TA Universal V4.5A software was used to analyze film thermograms.

\subsubsection{Microstructure of Composite Films}

The cross-section of ESG 100, EPI 100 and EPI 50/ESG 50 blend films and emulsified film were investigated using scanning electron microscopy (SEM, Hitachi S4800, Tokyo, Japan), at an angle of $90^{\circ}$ to the surface and below an accelerating voltage of $2.0 \mathrm{kV}$, using different magnifications. The films 
were cryofractured by engagement in liquid nitrogen. Before visualization, samples were cut and fixed through double side adhesive tape on the SEM support and observed at a magnification of $2000 \times$ and a pressure of $60 \mathrm{~Pa}$.

\subsection{In-Vitro Antioxidant Activity of the Films}

The ability of films to reduce iron (III) was determined according to the method of Yildirim et al., [22]. The iron chelating effect of films was estimated by the method of Decker and Welch [23]. Total antioxidant capacity is based on the reduction of Mo (VI) to Mo (V) by the sample [24].

\subsection{Statistical Analysis}

Statistical analyses were performed with SPSS ver. 17.0, professional edition using ANOVA analysis at a $(p$-value $<0.05)$. Duncan's multiple-range test ( $p$-value $<0.05)$ was used to detect differences among mean values of all the parameters analyzed for the different films. A standard deviation at the $95 \%$ confidence level was used to compare all parameters analyzed for the different film's ratios.

\section{Results and Discussion}

\subsection{Protein Content and SDS-PAGE Profiles of EPI and ESG}

\subsubsection{Physicochemical Composition of EPI and ESG}

Chemical compositions of fresh European eel muscle and freeze-dried EPI were described in our previous work [16]. Results show that alkali-aided process followed by centrifugation led to extract $94.33 \%$ of the total proteins. In addition, the highest solubility level of EPI (95\%) was observed at alkaline $\mathrm{pH}$ 10.0. Furthermore, the protein molecular weight distribution of EPI showed typical fish protein bands, including molecular heavy chain proteins $(>175 \mathrm{kDa})$ and actin bands $(\sim 45 \mathrm{kDa})$.

The proximate composition of skin and gelatin (ESG) from European eel skin was determined in Table 1. The skin was composed by $30.72 \% \pm 0.94 \%$ protein, $2.08 \% \pm 0.24 \%$ ash, $6.7 \% \pm 0.86 \%$ fat, and $58 \% \pm 2.25 \%$ moisture. ESG was characterized by high protein content $(90.5 \% \pm 0.70 \%)$ and a low amount of fat $(1.12 \% \pm 0.21 \%)$ suggesting the elimination of fat during gelatin extraction process [25]. The moisture content was in the vicinity of $6.1 \%$ which was within the limit prescribed for edible gelatin [26]. The ESG showed low water activity $(0.33 \pm 0.003)$, which is known to ensure microbiological stability.

Table 1. Physicochemical composition of skin (ES) and gelatin (ESG) from European eel.

\begin{tabular}{ccccc}
\hline Samples & Humidity (\%) & Protein (\%) & Lipid (\%) & Ash (\%) \\
\hline ES & $58 \pm 2.25^{\mathrm{a}}$ & $30.72 \pm 0.94^{\mathrm{b}}$ & $6.7 \pm 0.86^{\mathrm{a}}$ & $\pm 0.24^{\mathrm{a}}$ \\
ESG & $6.10 \pm 0.14^{\mathrm{b}}$ & $90.5 \pm 0.70^{\mathrm{a}}$ & $1.12 \pm 0.21^{\mathrm{b}}$ & $2.95 \pm 0.07^{\mathrm{a}}$ \\
\hline
\end{tabular}

Values are given as mean \pm standard deviation. $a$ and $b$ : different letters in the same column indicate significant differences $(p<0.05)$; ES-European eel skin; ESG-European skin gelatin.

\subsubsection{SDS Page of ESG}

The subunit components of European eel skin gelatin were analyzed by polyacrylamide gel electrophoresis in the presence of SDS. The SDS-PAGE pattern of gelatin showed two major bands in the molecular weight range of 97-200 kDa (Figure 1). These bands represent $\alpha$-chain and $\beta$-components. In addition, the SDS-PAGE pattern revealed number of low molecular weight bands which could be due to the degradation of $\alpha, \beta$, and $\gamma$ components during gelatin extraction [27]. The molecular weight of the extracted gelatin may be affected by the hydrolysis process that contributes to the dividing of the peptide bonds and also intermolecular cross links between peptide chains [28]. 


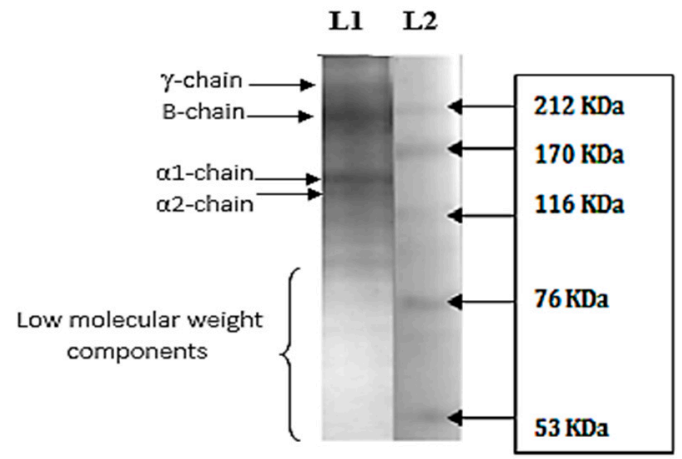

Figure 1. SDS-polyacrylamide gel electrophoresis of ESG, line 1(L1): ESG and line 2 (L2): high molecular weight marker.

\subsection{Characterization of EPI/ESG Blend Films}

\subsubsection{Color and Light Transmission of Films}

Color of films is crucial parameter in food packaging, which influence the visual inspection and the acceptability of consumer. The color of EPI, EPG, and EPI/ESG blend films was presented in Table 2. EPI film showed the highest $L$-value (85.55) and the lowest $b$ value (7.93). However, ESG film presented the lowest $L$ value (80.91) and the highest $b$ value (15.39) and $\Delta E$ value (8.78). Color results of blend films revealed that high amount of EPI leads to increasing $L$ value (lightness) from 81.64 for EPI 25/ESG 75 to 84.24 for EPI 75/ESG 25 and considerably reducing $b$ and $\Delta E$ values. Thus, the incorporation of ESG reduced $L$ and increased $b$ and $\Delta E$ values. The color changes of the obtained films were accredited to the important quantity of protein components (4\%) existing in gelatin film compared to that of protein isolate film (2\%). Consequently, the EPI integration in films based on gelatin influences significantly the color of resulting films.

Table 2. Color parameters of EPI, ESG, and EPI/ESG blend films. Color parameters of emulsified films (ratio EO:EPI/ESG = 1:4).

\begin{tabular}{|c|c|c|c|c|c|}
\hline \multirow{2}{*}{\multicolumn{2}{|c|}{$\begin{array}{c}\text { Films EPI/ESG } \\
(w / w)\end{array}$}} & \multicolumn{3}{|c|}{ Color Parameter } & \multirow[t]{2}{*}{$\Delta E$} \\
\hline & & $L$ & $a$ & $b$ & \\
\hline \multirow{5}{*}{ Not emulsified } & $100 / 0$ & $85.55 \pm 0.37^{a}$ & $-0.67 \pm 0.05^{\mathrm{a}}$ & $7.93 \pm 0.95^{c}$ & - \\
\hline & $75 / 25$ & $84.24 \pm 0.73^{a b}$ & $-0.61 \pm 0.06^{\mathrm{a}}$ & $8.15 \pm 0.43^{c}$ & $1.33 \pm 0.78^{c}$ \\
\hline & $50 / 50$ & $83.09 \pm 0.58 \mathrm{bcA}$ & $-0.58 \pm 0.01^{\mathrm{aB}}$ & $13.32 \pm 1.07^{b B}$ & $5.93 \pm 1.21 \mathrm{bB}$ \\
\hline & $25 / 75$ & $81.64 \pm 0.71^{\mathrm{cdA}}$ & $-0.61 \pm 0.08^{a B}$ & $13.35 \pm 0.01 \mathrm{bB}$ & $6.69 \pm 0.40^{b B}$ \\
\hline & $0 / 100$ & $80.91 \pm 1.18^{\mathrm{dA}}$ & $-0.55 \pm 0.02 \mathrm{aB}$ & $17.06 \pm 1.62^{\mathrm{aB}}$ & $8.78 \pm 0.90^{a B}$ \\
\hline \multirow{3}{*}{ Emulsified } & $0 / 100$ & $79.36 \pm 0.25^{\mathrm{bA}}$ & $0.91 \pm 0.16^{\mathrm{aA}}$ & $20.69 \pm 0.09^{\mathrm{aA}}$ & $14.27 \pm 1.01 \mathrm{aA}$ \\
\hline & $25 / 75$ & $80.55 \pm 0.09^{a A}$ & $0.41 \pm 0.05^{\mathrm{bA}}$ & $18.83 \pm 0.01^{\mathrm{bA}}$ & $12.04 \pm 1.02^{\mathrm{abA}}$ \\
\hline & $50 / 50$ & $81.58 \pm 0.50^{\mathrm{aA}}$ & $0.45 \pm 0.09^{\mathrm{bA}}$ & $17.56 \pm 0.38^{\mathrm{cA}}$ & $10.48 \pm 1.02^{\mathrm{bA}}$ \\
\hline
\end{tabular}

Values are given as mean \pm standard deviation. a-d: different letters in the same column indicate significant differences between sample of the non-emulsified film and the sample emulsified film (separately), A-B: different letters indicate significant differences in the same ratio EPI/ESG between emulsified and non-emulsified films $(p<0.05)$; ESG: European skin gelatin; EPI: European eel protein isolate.

The color parameters of emulsified films were presented in Table 2. Indeed, with EO incorporation, lightness of emulsified films decreased and $\Delta E$ increased, compared to the control film. Emulsified ESG 100 based film showed the lowest $L$ value (79.36) with unpredictably higher $b(20.69)$ and $\Delta E(14.27)$ values. Furthermore, lightness of emulsified films increased with protein isolate addition, from 79.36 to 81.58, for ESG 100 and EPI 50/ESG 50, respectively, which is in accordance with the obtained color traits of non-emulsified films. These findings are in line with the previous study of Tongnuanchan et al. [29].

Comestible films should prevent UV light transmission to protect foods against oxidation and to enhance its stability during conservation. The light transmittance at a selected wavelength (200-800 nm) 
of different films is presented in Table 3. ESG based film revealed the highest light absorbance reflecting its good UV barrier property, which allows it to protect the packaged foods against light oxidative deterioration [30]. The high UV barrier effect of gelatin film is mainly due to the high content of aromatic amino acids present in gelatin (phenylalanine and tyrosine) which absorb the UV light [31]. However, protein isolate addition increases the light transmittance of blend films. This data is correlated with the color of the added EPI component and approved the light barrier property of ESG film.

Table 3. Light transmittance (\%) of not emulsified and emulsified films (ratio EO:EPI/ESG = 1:4).

\begin{tabular}{cccccccccc}
\hline \multicolumn{2}{c}{ Films } & \multicolumn{7}{c}{ Light Transmittance (\%) } \\
\cline { 2 - 10 } EPI/ESG $(w / w)$ & $\mathbf{2 0 0}$ & $\mathbf{2 8 0}$ & $\mathbf{3 5 0}$ & $\mathbf{4 0 0}$ & $\mathbf{5 0 0}$ & $\mathbf{6 0 0}$ & $\mathbf{7 0 0}$ & $\mathbf{8 0 0}$ \\
\hline \multirow{3}{*}{ Not } & $100 / 0$ & 0.1 & 0.06 & 15.82 & 29.24 & 46.22 & 52.88 & 57.76 & 60.60 \\
\multirow{2}{*}{ Emulsified } & $75 / 25$ & 0.1 & 0.27 & 19.34 & 33.15 & 47.86 & 53.09 & 57.01 & 59.47 \\
& $50 / 50$ & 0.08 & 0.14 & 11.43 & 20.71 & 31.57 & 35.68 & 38.65 & 40.31 \\
& $25 / 75$ & 0.08 & 0.05 & 1.50 & 3.73 & 7.77 & 10.30 & 12.30 & 13.80 \\
\multirow{3}{*}{ Emulsified } & $0 / 100$ & 0.03 & 0.04 & 0.56 & 1.34 & 3.01 & 4.32 & 5.57 & 6.62 \\
& $0 / 100$ & 0.05 & 0.04 & 0.58 & 1.81 & 4.40 & 6.33 & 8.10 & 9.50 \\
& $25 / 75$ & 0.05 & 0.05 & 1.63 & 4.19 & 8.72 & 11.02 & 12.54 & 13.56 \\
& $50 / 50$ & 0.06 & 0.08 & 0.51 & 1.38 & 3.12 & 4.04 & 4.68 & 5.11 \\
\hline
\end{tabular}

These results could be related to the higher concentration of gelatin (4\%) used for film production compared to that of protein isolate $(2 \%)$. The light transmittance of the different emulsified films is presented in Table 3. Emulsified films displayed a lower light transmittance compared to the non-emulsified films $(p<0.05)$, suggesting that the incorporation of EO improved the UV barrier properties of films. This result is in line with previous study of Zhang et al. [32] who studied the effect of the addition of two types of waxes (beeswax and carnauba wax) on the functional properties of gelatin films and reported that the emulsified films have a higher opacity and UV-visible light barrier property than the wax-free film.

\subsubsection{Moisture Content and Solubility of Films}

The results of moisture content (MC) and water solubility of obtained films are presented in Table 4 . Film containing only gelatin (ESG100) exhibited significantly higher water content $(12.26 \%)$ than EPI100 film $(p<0.05)$. In addition, blend films presented intermediate MC values without significant differences among them $(p>0.05)$.

Table 4. Thickness, mechanical properties (Tensile strength (TS) and elongation at break (EAB)), moisture content, and solubility of films stored at the temperature $25^{\circ} \mathrm{C}$ and the $\mathrm{RH} 50 \%$.

\begin{tabular}{|c|c|c|c|c|c|c|}
\hline \multicolumn{2}{|c|}{$\begin{array}{c}\text { Films EPI/ESG } \\
(w / w)\end{array}$} & \multirow{2}{*}{$\begin{array}{c}\begin{array}{c}\text { Thickness } \\
(\mu \mathrm{m})\end{array} \\
32.00 \pm 4.32^{\mathrm{b}}\end{array}$} & \multirow{2}{*}{$\begin{array}{c}\text { TS (MPa) } \\
5.42 \pm 0.69^{\mathrm{c}}\end{array}$} & \multirow{2}{*}{$\begin{array}{c}\text { EAB (\%) } \\
2.14 \pm 0.02^{d}\end{array}$} & \multirow{2}{*}{$\begin{array}{c}\begin{array}{c}\text { Moisture Content } \\
\text { (g moisture/100 g film) }\end{array} \\
6.78 \pm 0.40^{\mathrm{d}}\end{array}$} & \multirow{2}{*}{$\begin{array}{c}\begin{array}{c}\text { Film Solubility } \\
(\mathbf{\%})\end{array} \\
29.47 \pm 1.03^{\mathrm{e}}\end{array}$} \\
\hline \multirow{5}{*}{$\begin{array}{c}\text { Not } \\
\text { Emulsified }\end{array}$} & $100 / 0$ & & & & & \\
\hline & $75 / 25$ & $50.78 \pm 3.03^{a}$ & $10.69 \pm 1.20^{b}$ & $8.55 \pm 0.61^{c}$ & $7.58 \pm 0.24^{\mathrm{c}}$ & $41.91 \pm 1.86^{\mathrm{d}}$ \\
\hline & $50 / 50$ & $52.60 \pm 2.41^{a}$ & $14.33 \pm 0.73^{a}$ & $15.00 \pm 0.68^{b}$ & $7.94 \pm 0.35^{\mathrm{cA}}$ & $64.99 \pm 2.07 \mathrm{cB}$ \\
\hline & $25 / 75$ & $56.25 \pm 4.79^{\mathrm{a}}$ & $16.34 \pm 0.30^{a}$ & $16.05 \pm 0.62^{b}$ & $8.87 \pm 0.03^{b B}$ & $72.43 \pm 0.60 \mathrm{bB}$ \\
\hline & $0 / 100$ & $59.00 \pm 2.00^{a}$ & $16.58 \pm 0.32^{a}$ & $18.74 \pm 0.74^{a}$ & $12.26 \pm 0.10^{\mathrm{aA}}$ & $93.01 \pm 0.54 \mathrm{aB}$ \\
\hline \multirow{3}{*}{ Emulsified } & $0 / 100$ & ND & ND & ND & $10.12 \pm 0.60 \mathrm{aB}$ & $96.51 \pm 2.06^{\mathrm{aA}}$ \\
\hline & $25 / 75$ & ND & ND & ND & $10.36 \pm 0.99 \mathrm{aA}$ & $91.64 \pm 0.39 \mathrm{bA}$ \\
\hline & $50 / 50$ & ND & ND & ND & $8.36 \pm 1.35^{\mathrm{aA}}$ & $87.06 \pm 0.99 \mathrm{cA}$ \\
\hline
\end{tabular}

Values are given as mean \pm standard deviation. a-e: different letters in the same column indicate significant differences between samples of the non-emulsified and emulsified films (separately) $(p<0.05)$, A-B: different letters indicate significant differences in the same ratio EPI/ESG between emulsified and non-emulsified films $(p<0.05)$; ESG: European skin gelatin; EPI: European eel protein isolate. ND: Not Determined.

Furthermore, amongst all films, EPI 100 film had the lowest solubility (29.47\%), while ESG 100 film had the highest solubility level (93\%). This finding is in line with previous works of Arfat et al. [33] and Kchaou et al. [7]. The obtained result indicates the poor water resistance of ESG film, owing 
to the hydrophilic group of the gelatin. Thus, water solubility of films was reduced by increasing the amount of EPI. This finding could be related to the establishment of covalent bonds between EPI proteins such as disulfide covalent bonds [34]. Furthermore, film solubility is related to the surface hydrophobicity of the EPI, compared to the gelatin [35], subsequent in the lower hydrophilic sites accessible for absorbing water [36].

Regarding emulsified films, increasing EPI content in the emulsified film matrix reduced their solubility (Table 4). Indeed, EF-ESG 100, EF-EPI 25/ESG 75, and EF-EPI 50/ESG 50 had high-water solubility compared to the free oil-based films, reaching $96.51 \%, 91.64 \%$, and $87.06 \%$, respectively. Moreover, EF-ESG 100 had the highest solubility, followed by EF-EPI 25/ESG 75 and EF-EPI 50/ESG 50. The obtained results could be related to the higher stability of emulsion as presented in Figure 2, resulting in more uniform emulsion for EF-ESG 100.

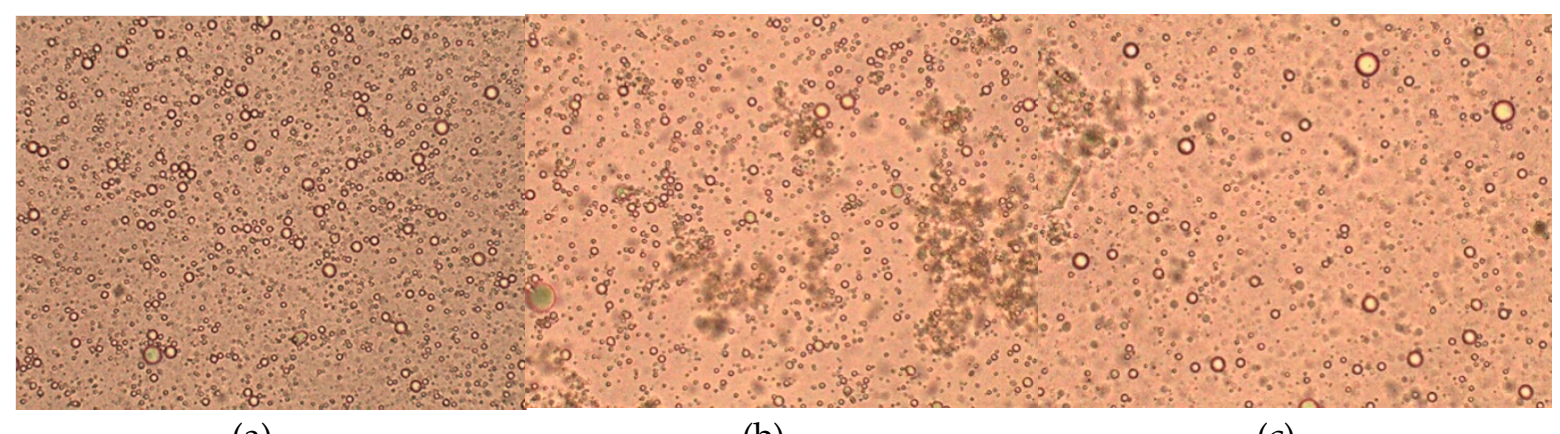

(a)

(b)

(c)

Figure 2. Microscopy optic observation of emulsions stabilized by protein isolate (EPI) film, gelatin (ESG) used for the preparation of emulsified films EPI/ESG: (a) 0/100, (b) 25/75, and (c) 50/50 using the optical microscope (Motic, ME 2000) (400×).

This finding could be related to the functional properties of ESG, such as its higher solubility and emulsifying activity. The strong correlation between solubility and the emulsifying property has been established [37]. In fact, high solubility level improves protein migration to the oil/water interface, allowing the appropriate rearrangement at the interfacial film [38]. In addition, the nature of incorporated lipids affects the permeability of some compounds in the emulsified films. Monedero et al. [39] stated that the apparent diffusion coefficient in whey protein films containing beeswax is lower than in the films containing oleic acid. Thus, the more the lipid is solid, such as waxes, the more the diffusion in the film will be limited.

\subsubsection{FTIR Spectra}

As can be seem in Figure 3a, the different spectra of films showed characteristic pics of protein at approximately $1230-1340 \mathrm{~cm}^{-1}, 1540-1610 \mathrm{~cm}^{-1}, 1560-1680 \mathrm{~cm}^{-1}, 2920-2945 \mathrm{~cm}^{-1}$, and $3300-3500$ $\mathrm{cm}^{-1}$ correlated to amide-III (correlated to the vibrations in plane of $\mathrm{C}-\mathrm{N}$ and $\mathrm{N}-\mathrm{H}$ groups of bound amide or vibrations of $\mathrm{CH}_{2}$ groups of glycine), amide-II (arising from bending vibration of $\mathrm{N}-\mathrm{H}$ groups and stretching vibrations of $\mathrm{C}-\mathrm{N}$ groups), amide-I (representing to $\mathrm{C}=\mathrm{O}$ stretching/hydrogen bonding coupled with $-\mathrm{COO}$ ), amide- $\mathrm{B}$ (asymmetric stretching vibration of $=\mathrm{C}-\mathrm{H}$ and $-\mathrm{NH}^{3+}$ ) and amide- $\mathrm{A}$ (corresponding to NH-stretching coupled with hydrogen bonding), respectively [40]. In addition, all films presented an absorption band placed at the wavenumber of $1036-1039 \mathrm{~cm}^{-1}$ correlated to the interactions between film structure and $\mathrm{OH}$ group of glycerol used as plasticizer [36]. Furthermore, the absorbance peak of amide A, at $3286-3289 \mathrm{~cm}^{-1}$ regions, was ascribed to the interaction between polymers and water (Figure 3a). The decrease in $\mathrm{N}-\mathrm{H}$ vibration band wavenumber and lengthening with ESG increasing content in the film may indicate the increase and reinforcement of interaction between gelatin and EPI via hydrogen bonding [36]. Kchaou et al., [7] stated that protein could also interact through hydrophobic bonds among hydrophobic aromatic amino acids of the cuttlefish 
gelatin and protein isolate. According to Cao et al., [41], the interactions between the amino and carboxyl groups of soy protein isolate and gelatin could significantly affect the mechanical properties of composite films and hydrogen bonding. It is interesting to note a notable change in the absorbance of amide I, which attained 1607, 1694, and $1645 \mathrm{~cm}^{-1}$ for ESG 100, EPI 50/ESG 50, and EPI 100, and could be associated to gelatin secondary structure alterations [42]. Otherwise, compared to the gelatin film profile, the amplitude of amide III band was decreased for ESG 100, EPI 50/ESG 50, and EPI 100 by the EPI content increasing. This change could be related to electrostatic interactions establish between amino and carbonyl groups of polymers, as described by Gomez-Guillen et al. [43]. Thus, FTIR analysis proved the presence of interactions between ESG and EPI in the composite biofilms.

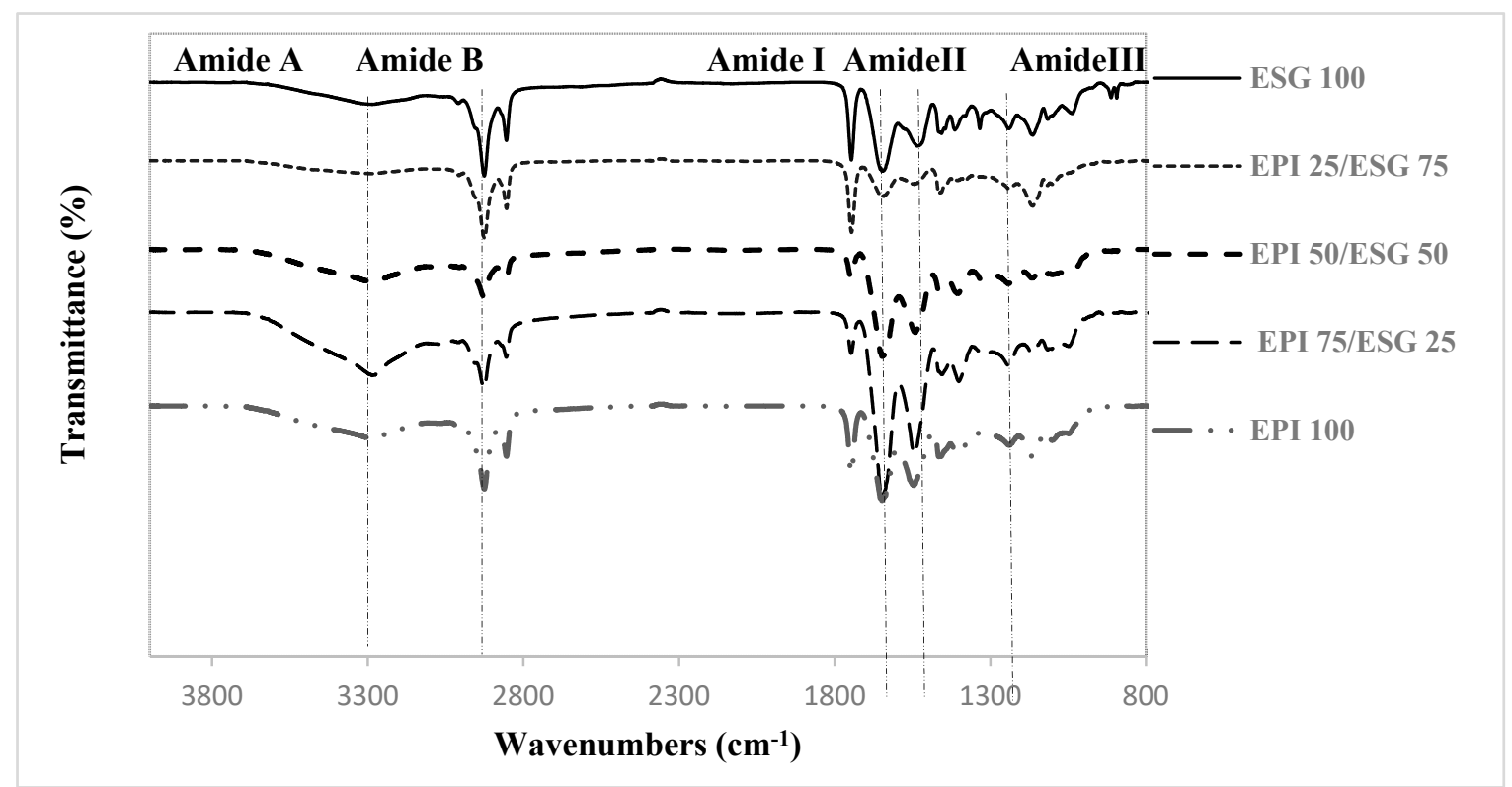

(a)

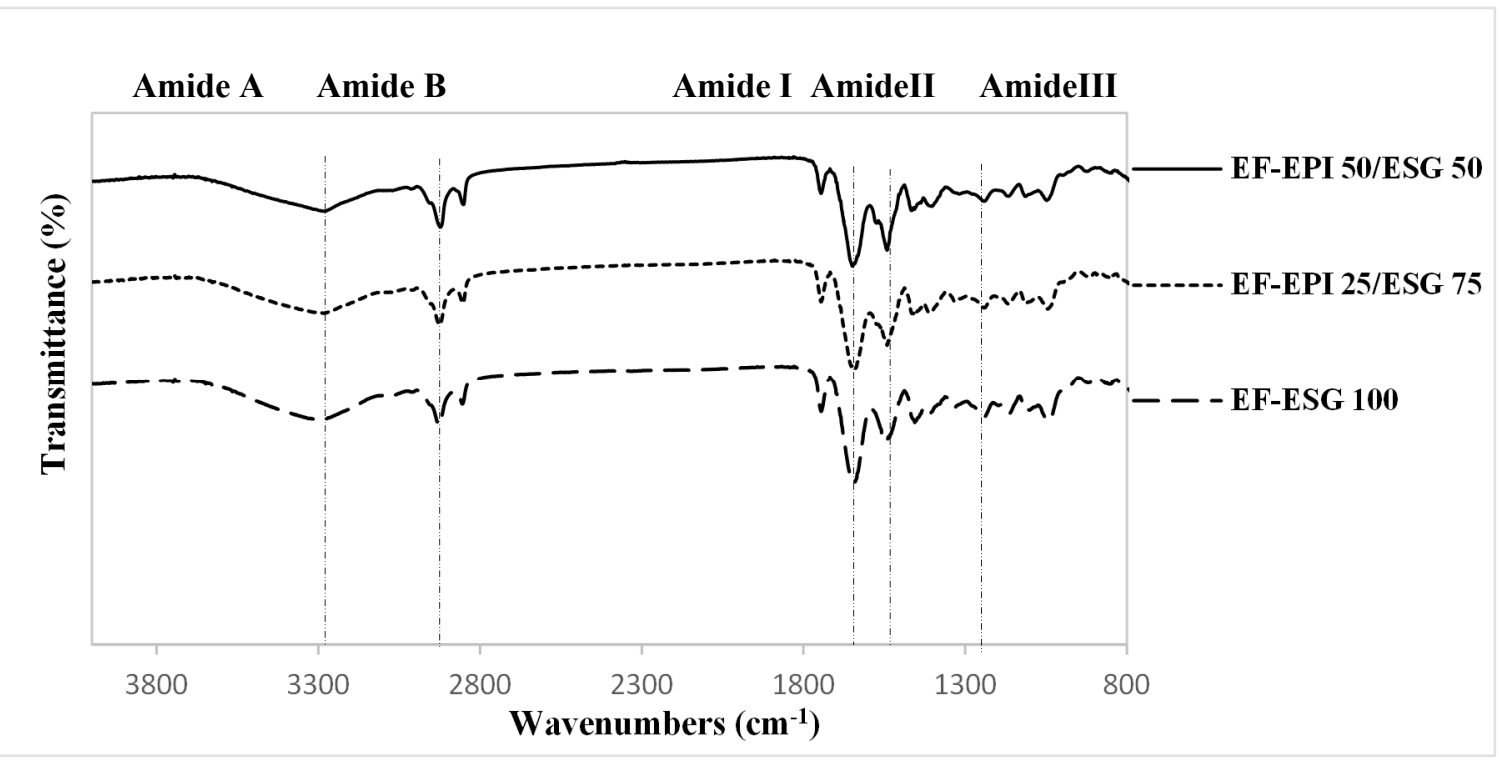

(b)

Figure 3. Fourier transform infrared spectra of (a) EPI film, ESG film, and EPI/ESG blend films and (b) emulsified films EPI/ESG. 
The different spectra of emulsified films presented in Figure $3 b$ showed characteristic peaks of proteins and the presence of specific bands of $\mathrm{EO}$ at 1740,1711 , and $1640 \mathrm{~cm}^{-1}$, corresponding to $\mathrm{C}=\mathrm{C}$, $\mathrm{C}=\mathrm{O}$, and $\mathrm{C}=\mathrm{C}-\mathrm{C}=\mathrm{C}[44,45]$. A specific absorption band of omega- 3 in emulsified film, related to polyunsaturated fatty acid, was detected at $3012 \mathrm{~cm}^{-1}$ (Figure $3 \mathrm{~b}$ ), which corresponds to the $\mathrm{C}-\mathrm{H}$ stretching of cis-alkene $(-\mathrm{HC}=\mathrm{CH}-)$ [46].

\subsubsection{Mechanical Properties}

The mechanical properties of films were assessed through the determination of TS (MPa) and EAB (\%) values, except for the emulsified films which were relatively sticky to be peeled off from the Petri dishes.

The results, illustrated in Table 4, showed that film prepared with $100 \%$ ESG exhibited the highest tensile strength $(16.58 \mathrm{MPa})$ and elongation at break (18.74\%) values. However, EPI-based film displayed the lowest EAB (2.14\%) and TS (5.42 MPa) levels, which increase with the rise of ESG concentration. Thus, the increase of gelatin concentration ameliorates the mechanical properties of blend films, contrary to the EPI 100 based film which might not form a robust film network. This finding could be related to the lower reactivity of myofibrillar protein molecules in cross-linking or interaction between protein molecules [33]. Moreover, gelatin is cross linked with itself or with EPI in the film matrix and this interaction was made via hydrogen bonds [47]. This finding resulted to the improvement of mechanical properties of blend films. Consequently, the mechanical properties of ESG/EPI blend films were largely affected by the type of protein, the interaction and the ratio of used proteins as well as the number of interactions involved in the film matrix [36].

Thickness of EPI, ESG, and EPI/ESG blend films are presented in Table 4. EPI films had lower thickness $(32 \mu \mathrm{m})$, compared to ESG film $(59 \mu \mathrm{m})$. In fact, thickness increased with gelatin addition, which could be related to the higher concentration of gelatin (4\%) used in the film's preparation based on the dry weight matter compared to that of protein isolate. However, Denavi et al., [35] found similar thickness in soy protein isolate and gelatin-based film, regardless of the proportion of SPI was used.

\subsubsection{Thermal Properties}

The glass transition temperature (Tg) of films, determined through the DSC curves, is reported in Table 5. As can be seen, ESG film showed higher $\mathrm{Tg}$, by about $71.51{ }^{\circ} \mathrm{C}$, than the $\mathrm{Tg}$ of EPI film $\left(50.98^{\circ} \mathrm{C}\right)$, which could be related to the triple helix structure of gelatin.

Table 5. Thermal properties of ESG, EPI, and ESG/EPI composite films; Thermal properties of ESG, and ESG/EPI blend emulsified films (ratio EO:EPI/ESG = 1:4) (Emulsified and not emulsified film were previously incubated at $25^{\circ} \mathrm{C}$ and $0 \% \mathrm{RH}$ ).

\begin{tabular}{ccccc}
\hline \multicolumn{2}{c}{$\begin{array}{c}\text { Film EPI/ESG } \\
(\boldsymbol{w} / \boldsymbol{w})\end{array}$} & Tg & Onset T $\left({ }^{\circ} \mathbf{C}\right)$ & Offset T $\left({ }^{\circ} \mathbf{C}\right)$ \\
\hline & $100 / 0$ & 50.98 & 50.58 & 51.18 \\
Not Emulsified & $75 / 25$ & 54.34 & 53.92 & 54.46 \\
& $50 / 50$ & 57.43 & 46.15 & 59.43 \\
& $25 / 75$ & 64.89 & 64.36 & 46.90 \\
& $0 / 100$ & 71.51 & 70.36 & 72.37 \\
Emulsified & $0 / 100$ & 86.24 & 86.12 & 86.72 \\
& $25 / 75$ & 73.90 & 59.69 & 60.92 \\
& $50 / 50$ & 60.38 & 71.63 & 76.86 \\
\hline
\end{tabular}

The obtained Tg of ESG film was in line with those of triggerfish acidic gelatin $\left(77^{\circ} \mathrm{C}\right)[48]$ and higher than that of gelatin extracted from skin cuttlefish $\left(60^{\circ} \mathrm{C}\right)$ [7] and smooth hound $\left(66.94{ }^{\circ} \mathrm{C}\right)$ [49]. The difference of Tg among ESG and EPI films is mostly attributed to the different molecular structure, which resulted in different molecular arrangement and interactions [50]. 
For the blend films, the incorporation of EPI to the gelatin formulation reduced the $\mathrm{Tg}$ value of films. In fact, Tg decrease significantly with increasing EPI content from $71.51^{\circ} \mathrm{C}$ for ESG 100 based film to $54.34{ }^{\circ} \mathrm{C}$ for EPI25/75ESG-based film. This finding was in line with the previous study of Akköse et al. [51] who find that addition of biopolymer levels significantly affected the transition temperature values. The DSC results, which were in accordance with the mechanical properties, confirmed the biocompatibility between the two polymers and the formation of hydrogen interactions between them. Thus, a positive correlation between Tg and TS values of the films could be noticed. This finding is in line with previous works of Arfat et al. [52] and Abdelhedi et al., [49] who found that TS for fish gelatin films increased with increasing Tg. TS increasing could be attributed to the formation of a denser matrix subsequently gelatin addition due to the interaction between the two biopolymers (EPI and ESG).

The thermal analysis of emulsified films, presented in Table 5, revealed that $\mathrm{Tg}$ of all emulsified films $\left(71.51-86.24^{\circ} \mathrm{C}\right)$ were higher than the Tg of not-emulsified films. Akköse et al. [51] reported that increasing the $\mathrm{Tg}$ by addition of biopolymers leads to extend the food shelf life and this approach would be feasible only for fabricated foods. Furthermore, the Tg of emulsified film increased with gelatin amount increasing, reaching $60.38,73.90$, and $86.24^{\circ} \mathrm{C}$, for EF-EPI 50/ESG 50, EPI 25/ESG 75, and EF-ESG 100, respectively. This finding approved that EO was appropriately incorporated in the emulsified film, which is in accordance with the enhancement of the UV barrier properties of emulsified films and the presence of a characteristic band at $3012 \mathrm{~cm}^{-1}$, corresponding to the polyunsaturated fatty acid after the European oil incorporation. Thus, the increase of $\mathrm{Tg}$ value is related to the introduction of the cross-linking points which is responsible for reducing the mobility of chain segments in the matrix of the emulsified film compared to that prepared without oil [53]. Oil incorporation to the film matrix is a good alternative especially for the stabilization of frozen food as it protects against the water diffusion [54].

\subsubsection{Microstructure of Films}

Freeze-fractured cross-sectional images of EPI, ESG, and EPI/ESG blend films carried out via the scanning electron microscopy (SEM) are presented in Figure 4. Films elaborated with 100\% ESG and $100 \%$ EPI had a smooth, compact, and homogeneous structure on the cross-section. These results were in accordance with findings obtained by Jiang et al., [55] and Pereda et al., [56], showing no porosity, smooth, and homogeneous film microstructure for gelatin-chitosan blends. The cross-sectional image of EPI 50/ESG 50 blend film showed continuous microstructure, indicating the compatibility and the enhancement of the molecular interaction of polymer in the film matrix.

On the other hand, the cross-section combining gelatin with EPI in the ratio of 50:50 (w/w) displayed a rougher microstructure, which is in line with previous studies of Hoque et al., [36] and Abdelhedi et al., [49]. The roughness of blend films was probably due to the re-arrangements of protein molecules chains during films formation. Therefore, the microstructures could be related to the types of proteins and the interaction of proteins in film matrix in consort with the blend ratio of protein components designed for film preparation [36].

SEM micrographs of emulsified films cross-section revealed a smooth and homogeneous microstructure, with no phase separation, indicating high compatibility between EO and the gelatin [57]. The appropriate homogenous microstructure of the emulsified films with higher content of ESG (EPI/ESG 0/100 and EPI/ESG 25/75) is related to the interesting emulsifying property of ESG, allowing the encapsulation of the $\mathrm{EO}$ and the enhancement of the shrinkage of film network. However, the increasing of EPI content in the emulsified film (EF-EPI 50/ESG 50) resulted in the presence of cracks (Figure $4 \mathrm{~F}$ ) and droplets of oil floating towards the surface of film, suggesting that EPI 50/ESG 50 was not able to incorporate the EO in the film network [30]. 


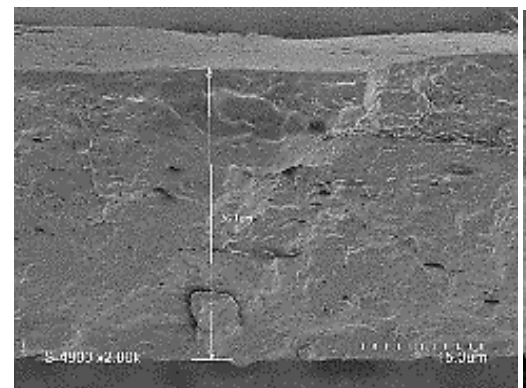

(A)

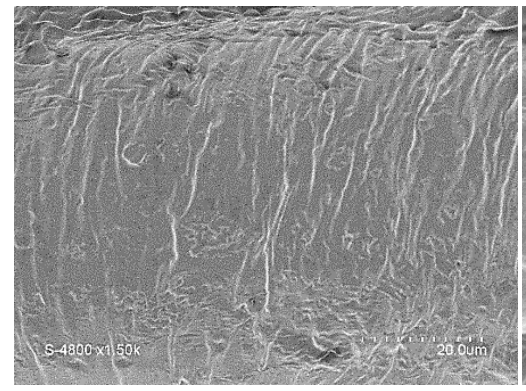

(D)

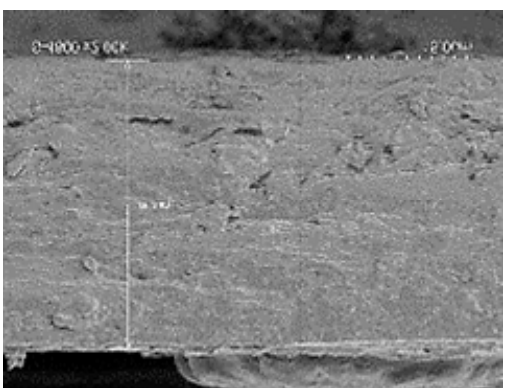

(B)

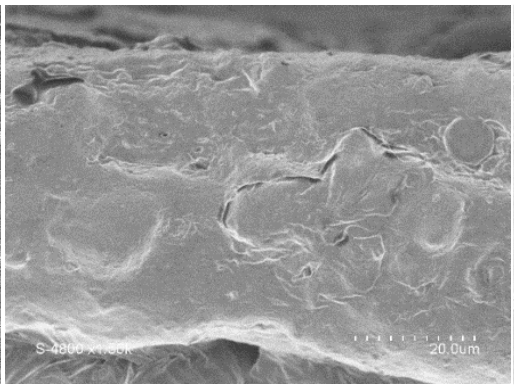

(E)

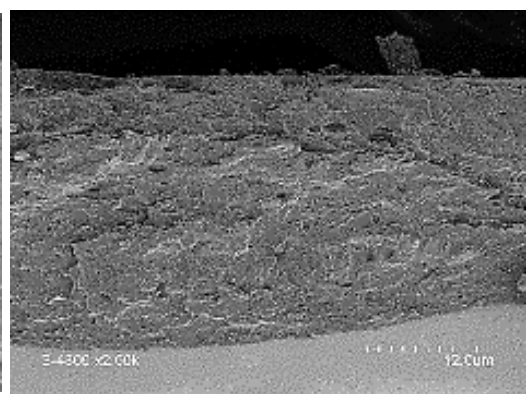

(C)

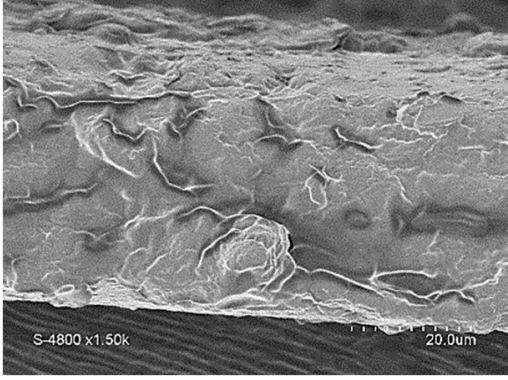

(F)

Figure 4. SEM micrographs (cross-section) of EPI/ESG: (A) 0/100, (B) 100/0, and (C) EPI 50/ESG 50 blend films and emulsified films EPI/ESG: (D) 0/100, (E) 25/75, and (F) 50/50.

\subsubsection{Antioxidant Activity of Films}

Antioxidant packaging is considered as categories among the requested active packaging, owing to their promising effect on spreading foods shelf life, avoiding the oxidative stress caused by the free radicals, which is involved in the development of many human diseases [58].

The chelating effect analysis, illustrated in Figure $5 a$, revealed an interesting activity for all films tested, ranged from $64 \%$ to $100 \%$. In fact, EPI film displayed the highest chelating power $(100 \%)$, while, ESG films exhibited the lowest antioxidant ability (64.30\%). Thus, adding EPI to blend films enhanced their iron chelating effect, reaching $92.02 \%, 97.80 \%$, and 99.04\% for EPI 25/ESG 75, EPI 50/ESG 50, and EPI 75/ESG 25 films, respectively.

Additionally, the results showed that the chelating activity of emulsified films decreased significantly with the incorporation of oil $(p>0.05)$. In fact, the EO addition to the EPI 50/ESG 50 film reduced its chelating activity from $97.80 \%$ to $42.93 \%$ (Figure $5 a$ ). This result is mainly due to the cross-linking points between polymer and $\mathrm{EO}$, which reduce the mobility of chain segments and ions in matrix of emulsified film compared to that prepared without oil [53].

Reducing effect determines the reducing aptitude versus ferric ion $\left(\mathrm{Fe}^{3+}\right)$, indicating the ability to donate an electron by the active compounds to the ion [59]. The reducing power of the different films is expressed as the absorbance at $700 \mathrm{~nm}$ (Figure 5b). Among all samples, EPI100-based film displayed the highest ability (0.79) to reduce ferric ion $\left(\mathrm{Fe}^{3+}\right)$, while ESG100-based film presented the poor reducing power (0.18). Thus, EPI addition improved the reducing potential of combined films. On the other hand, the reducing ability of emulsified films was considerably higher, compared to the non-emulsified films. Furthermore, increasing EPI amount in the emulsified film improved the reducing power ability reaching $\mathrm{OD}_{700}=0.72$ for EF-EPI 50/ESG 50 . 


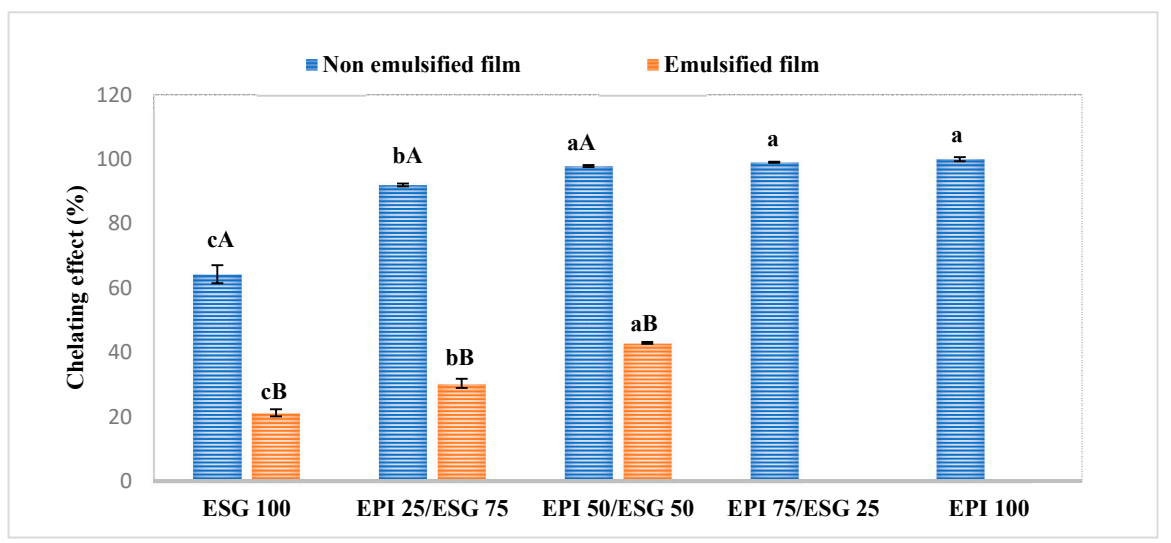

(a)

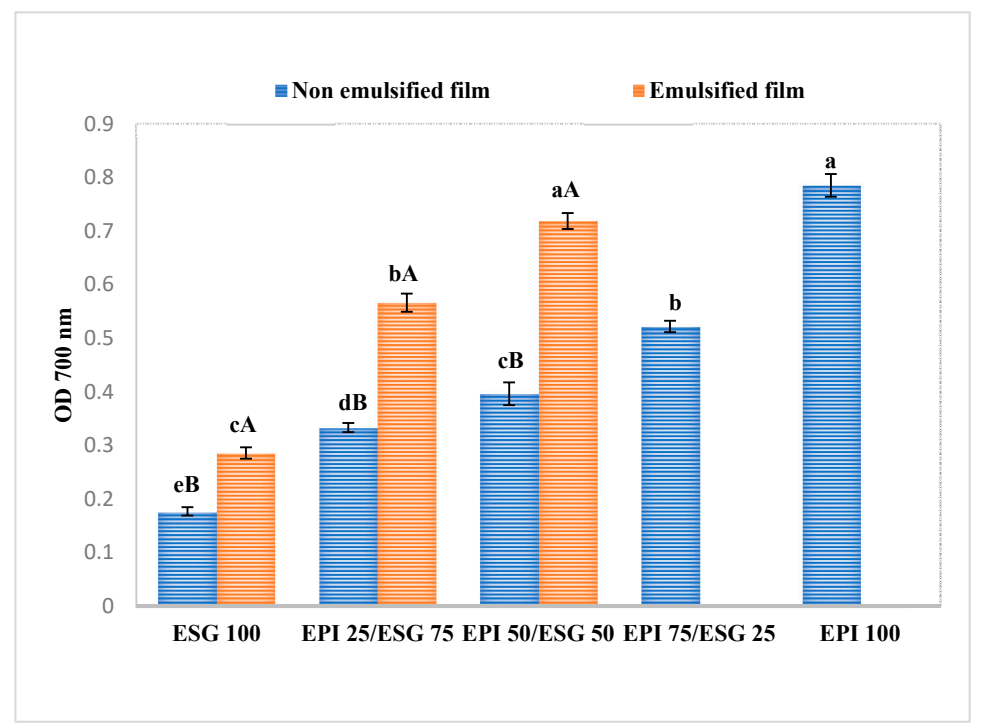

(b)

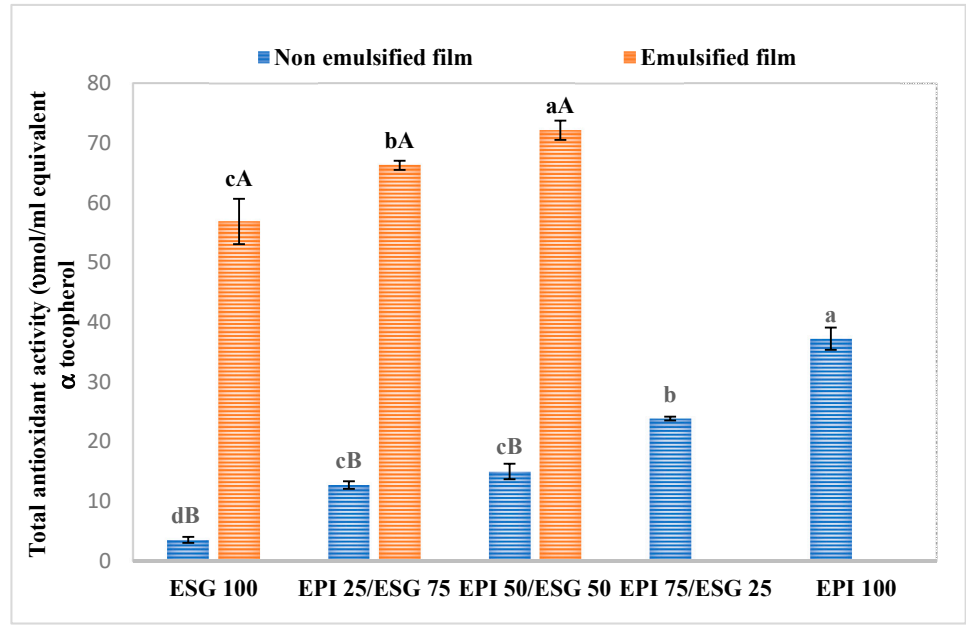

(c)

Figure 5. Antioxidant activity of protein isolate film (EPI) gelatin film (ESG) and EPI/ESG blend films and the emulsified film by the test of chelating power effect (a), ferric reducing activity (b), and total antioxidant activity (c). Values are assumed as mean \pm standard deviation. a-d: different letters indicate significant differences between sample of the non-emulsified film and the sample emulsified film (separately), A-B: different letters indicate significant differences in the same ratio EPI/ESG between emulsified and non-emulsified films ( $p<0.05)$; ES/European eel skin; ESG: European skin gelatin; EPI: European eel protein isolate. 
The antioxidant potential of enriched films comes from the bioactivity of the incorporated substances, which have proved their antioxidant effect as electron donors and chelating agents [49]. Likewise, total antioxidant capacity based on the reduction of Mo (VI) to Mo (V) expressed as a tocopherol equivalents (Figure $5 \mathrm{c}$ ) showed the highest activity $(37.24 \mu \mathrm{mol} / \mathrm{mL})$ for EPI100-based film and the lowest one was obtained by ESG100-based film $(3.69 \mu \mathrm{mol} / \mathrm{mL})$. The antioxidant activity of composite and emulsified films increased proportionally to the EPI content incorporated in the gelatin film formulation (Figure 5c). Furthermore, the incorporated of EO in the films improved the total antioxidant capacity reaching a maximum of $72.15 \mu \mathrm{mol} / \mathrm{mL}$ for EF-EPI50/ESG 50, compared to the non-emulsified EPI50/ESG $50(15 \mu \mathrm{mol} / \mathrm{mL})$. These findings are similar to the reducing ability and iron chelating result. Hence, all tests clearly indicated that the incorporation of EPI to ESG films enhanced the antioxidant activity of resulting blend films.

A previous study of Bao et al. [60] showed that specific amino acids (glycine and proline) are responsible for the antioxidant activity of gelatin which is improved considerably after protein isolate addition with is in line with the study of Kchaou et al. [7]. Moreover, antioxidant activity of the films is enhanced by the protein-protein interaction or hydrogen bonding forming the film network [61]. Furthermore, antioxidant activity of protein isolate is in correlation with the difference in the antioxidant efficiency of the added bioactive compounds present naturally in the protein. Additionally, antioxidant activity of peptide obtained after hydrolysis of protein isolate could be related to their sequence, composition, and hydrophobicity [62].

\section{Conclusions}

A characterization of blend biofilms based on European eel skin gelatin (ESG), protein isolate (EPI), and oil (EO) was released. The gelatin-based film displayed the highest tensile strength, elongation at break, and thermal properties, compared to EPI-based film and EPI/ESG blend films. Moreover, gelatin film presented the highest water solubility. Interestingly, the incorporation of EPI to the gelatin films matrix improved their antioxidant activity. The homogeneous microstructure was related with the better mechanical and physical characteristics of films. The cross-section combining gelatin with protein isolate (ratio 50:50) displayed a rougher microstructure correlated to the arrangements of protein molecules during films formation. ESG100 and EPI 25/ESG 75 films revealed a smooth and homogeneous microstructure. Additionally, the incorporation of EO improved the UV barrier properties of ESG/EPI films and their antioxidant activity, while their mechanical resistance was relatively affected. The different properties of the produced films give them the prospect of being effectively used in food industries as bioactive packaging to improve the shelf-life of bio-packaged foods.

Author Contributions: Conceptualization, W.T.; Methodology, W.T. and H.K.; Validation, M.H. and H.K.; Formal Analysis, S.L. and M.K.-C.; Investigation, M.K.-C. and R.N.; Data Curation, R.N. and M.K.-C.; Writing-Original Draft Preparation, W.T.; Writing-Review and Editing, M.K.-C., R.N. and M.N.; Supervision, M.K.-C. All authors have read and agreed to the published version of the manuscript.

Funding: This research was funded by the Ministry of Higher Education and Scientific Research-Tunisia.

Acknowledgments: The present work was funded by the Ministry of Higher Education and Scientific Research, Tunisia.

Conflicts of Interest: The authors declare no conflict of interest.

\section{References}

1. Andrade, R.M.S.; Ferreira, M.S.L.; Gonçalves, E.C.B.A. Development and characterization of edible films Based on fruit and vegetable residues. J. Food Sci. 2016, 81, 412-418. [CrossRef]

2. Chen, H.; Hu, X.; Chen, E.; Wu, S.; Mc Clements, D.J.; Liu, S.; Li, B.; Li, Y. Preparation, characterization, and properties of chitosan films with cinnamaldehyde nano emulsions. Food Hydrocoll. 2016, 61, 662-671. [CrossRef]

3. Campos, C.A.; Gerschenson, L.N.; Flores, S.K. Development of edible films and coatings with antimicrobial activity. Food Bioprocess Technol. 2011, 4, 849-875. [CrossRef] 
4. $\quad$ Romani, V.P.; Olsen, B.; Collares, M.P.; Oliveira, J.R.M.; Prentice-Hernández, C.; Martins, V.G. Improvement of fish protein films properties for food packaging through glow discharge plasma application. Food Hydrocoll. 2019, 87, 970-976. [CrossRef]

5. Hamdi, M.; Nasri, R.; Li, S.; Nasri, M. Bioactive composite films with chitosan and carotenoproteins extract from blue crab shells: Biological potential and structural, thermal, and mechanical characterization. Food Hydrocoll. 2019, 89, 802-812. [CrossRef]

6. Vahedikia, N.; Garavand, F.; Tajeddin, B.; Cacciotti, I.; Jafari, S.M.; Omidi, T.; Zahedi, Z. Biodegradable zein film composites reinforced with chitosan nanoparticles and cinnamon essential oil: Physical, mechanical, structural and antimicrobial attributes. Colloids Surf. B 2019, 177, 25-32. [CrossRef] [PubMed]

7. Kchaou, H.; Jridi, M.; Abdelhedi, O.; Benbettaieb, N.; Karbowiak, T.; Nasri, M.; Debeaufort, F. Development and characterization of cuttlefish (Sepia officinalis) skin gelatin-protein isolate blend films. Int. J. Biol. Macromol. 2017, 105, 1491-1500. [CrossRef] [PubMed]

8. Lee, K.; Bin, S.K. Preparation and Characterization of an Olive Flounder (Paralichthys olivaceus) Skin Gelatin and Polylactic Acid Bilayer Film. J. Food Sci. 2016, 82, 706-710. [CrossRef]

9. Tongnuanchan, P.; Benjakul, S.; Prodpran, T.; Songtipya, P. Characteristics of film based on protein isolate from red tilapia muscle with negligible yellow discoloration. Int. J. Biol. Macromol. 2011, 48, 758-767. [CrossRef]

10. Paschoalick, T.M.; Garcia, F.T.; Sobral, P.J.A.; Habitante, A.M.Q.B. Characterisation of some functional properties of edible films based on muscle proteins of Nile tilapia. Food Hydrocoll. 2003, 17, 419-427. [CrossRef]

11. Rocha, M.D.; Loiko, M.R.; Gautério, G.V.; Tondo, E.C.; Prentice, C. Influence of heating, protein and glycerol concentrations of film-forming solution on the film properties of Argentine anchovy (Engraulis anchoita) protein isolate. J. Food Eng. 2013, 116, 666-673. [CrossRef]

12. Khan, I.; Mansha, M.; Mazumder, M.A.J.; Jafar Mazumder, M.A. Functional Polymers, 1st ed.; Springer: Berlin, Germany, 2018.

13. Kokoszka, S.; Debeaufort, F.; Lenart, A.; Voilley, A. Liquid and vapor water transfer through whey protein/lipid emulsion films. J. Sci. Food Agric. 2010, 90, 1673-1680. [CrossRef] [PubMed]

14. Arab-Tehrany, E.; Jacquot, M.; Gaiani, C.; Imran, M.; Desobry, S.; Linder, M. Beneficial effects and oxidative stability of omega-3 long-chain polyunsaturated fatty acids. Trends Food Sci. Technol. 2012, 25, 24-33. [CrossRef]

15. Limpisophon, K.; Tanaka, M.; Osako, K. Characterization of gelatin-fatty acid emulsion films based on blue shark (Prionace glauca) skin gelatin. Food Chem. 2010, 122, 1095-1101. [CrossRef]

16. Taktak, W.; Nasri, R.; Hamdi, M.; Gomez-Mascaraque, L.G.; Lopez-Rubio, A.; Li, S.; Nasri, M.; Chaâbouni-Karra, M. Physicochemical, textural, rheological and microstructural properties of protein isolate gels produced from European eel (Anguilla anguilla) by heat-induced gelation process. Food Hydrocoll. 2018, 82, 278-287. [CrossRef]

17. Taktak, W.; Nasri, R.; Lopez-Rubio, A.; Hamdi, M.; Gomez-Mascaraque, L.G.; Ben Amor, N.; Kabadou, A.; Li, S.; Nasri, M.; Chaâbouni-Karra, M. Improved antioxidant activity and oxidative stability of spray dried European eel (Anguilla anguilla) oil microcapsules: Effect of emulsification process and eel protein isolate concentration. Mater. Sci. Eng. C 2019, 104, 109867. [CrossRef]

18. Jridi, M.; Nasri, R.; Lassoued, I.; Souissi, N.; Mbarek, A.; Barkia, A.; Nasri, M. Chemical and biophysical properties of gelatins extracted from alkali-pretreated skin of cuttlefish (Sepia officinalis) using pepsin. Food Res. Int. 2013, 54, 1680-1687. [CrossRef]

19. Folch, J.; Lees, M.; Sloane Stanley, G.H. A simple method for the isolation and purification of total lipids from animal tissues. J. Biol. Chem. 1957, 226, 497-509.

20. Gennadios, A.; Handa, A.; Froning, G.W.; Weller, C.L.; Hanna, M.A. Physical properties of egg white-dialdehyde starch films. J. Agric. Food. Chem. 1998, 46, 1297-1302. [CrossRef]

21. ISO 527-3:1995. Plastics—Determination of Tensile Properties-Part 3: Test Conditions for Films and Sheets; ISO: Geneva, Switzerland, 1995.

22. Yildirim, A.; Mavi, A.; Oktay, M.; Kara, A.A.; Algur, O.F.; Bilaloglu, V. Comparison of antioxidant and antimicrobial activities of tilia (Tilia arentea Desf Ex DC) sage (Salvia triloba L.) and black tea (Camellia sinensis L.) extracts. J. Agric. Food. Chem. 2001, 48, 5030-5034. [CrossRef] 
23. Decker, E.A.; Welch, B. Role of ferritin as a lipid oxidation catalyst in muscle food. J. Agric. Food. Chem. 1990, 38, 674-677. [CrossRef]

24. Prieto, P.; Pineda, M.; Aguilar, M. Spectrophotometric quantitation of antioxidant capacity through the formation of a phosphor molybdenum complex: Specific application to the determination of vitamin E. Anal. Biochem. 1999, 269, 337-341. [CrossRef]

25. Jongjareonrak, A.; Benjakul, S.; Visessanguan, W.; Tanaka, M. Skin gelatin from bigeye snapper and brownstripe red snapper: Chemical compositions and effect of microbial transglutaminase on gel properties. Food Hydrocoll. 2006, 20, 1216-1222. [CrossRef]

26. Monograph, G.M.E. Standard Methods for the Testing of Edible Gelatin; Europe (GME) Monograph: Brussels, Belgium, 2000.

27. Duan, R.; Zhang, J.; Liu, L.; Cui, L.; Regensteinhe, M.J. Functional properties and application of gelatin derived from the skin of channel catfish (Ictalurus punctatus). Food Chem. 2018, 239, 464-469. [CrossRef]

28. Sarbon, N.M.; Badii, F.; Howell, N.K. The effect of chicken skin gelatin and whey protein interactions on rheological and thermal properties. Food Hydrocoll. 2015, 45, 83-92. [CrossRef]

29. Tongnuanchan, P.; Benjakul, S.; Prodpran, T.; Nilsuwan, K. Emulsion film based on fish skin gelatin and palm oil: Physical, structural and thermal properties. Food Hydrocoll. 2015, 48, 248-259. [CrossRef]

30. Iwata, K.; Ishizaki, S.; Handa, A.; Tanaka, M. Preparation and characterization of edible films from fish water-soluble proteins. Fish. Sci. 2000, 66, 372-378. [CrossRef]

31. Jiang, Y.; Tang, C.H.; Wen, Q.B.; Li, L.; Yang, X.Q. Effect of processing parameters on the properties of transglutaminase-treated soy protein isolate films. Innovative Food Sci. Emerg. Technol. 2007, 8, 218-225. [CrossRef]

32. Zhang, Y.; Simpson, B.K.; Dumont, M.J. Effect of beeswax and carnauba wax addition on properties of gelatin films: A comparative study. Food Biosci. 2018, 26, 88-95. [CrossRef]

33. Arfat, Y.A.; Benjakul, S.; Prodpran, T.; Osako, K. Development and characterization of blend films based on fish protein isolate and fish skin gelatin. Food Hydrocoll. 2014, 39, 58-67. [CrossRef]

34. Chinabhark, K.; Benjakul, S.; Prodpran, T. Effect of $\mathrm{pH}$ on the properties of protein-based film from bigeye snapper (Priacanthustayenus) surimi. Bioresour. Technol. 2007, 98, 221-225. [CrossRef]

35. Denavi, G.A.; Perez-Mateos, M.; Anon, M.C.; Montero, P.; Mauri, A.N.; Guillen, M.C.G. Structural and functional properties of soy protein isolate and cod gelatin blend films. Food Hydrocoll. 2009, 23, 2094-2101. [CrossRef]

36. Hoque, M.S.; Benjakul, S.; Prodpran, T.; Songtipya, P. Properties of blend film based on cuttlefish (Sepia pharaonis) skin gelatin and mung bean protein isolate. Int. J. Biol. Macromol. 2011, 49, 663-673. [CrossRef] [PubMed]

37. Burger, T.G.; Zhang, Y. Recent Progress in the Utilization of Pea Protein as an Emulsifier for Food Applications. Trends Food Sci. Technol. 2019, 86, 25-33. [CrossRef]

38. Shevkani, K.; Singh, N.; Kaur, A.; Rana, J.C. Structural and functional characterization of kidney bean and field pea protein isolates: A comparative study. Food Hydrocoll. 2015, 43, 679-689. [CrossRef]

39. Monedero, F.M.; Hambleton, A.; Talens, P.; Debeaufort, F.; Chiralt, A.; Voilley, A. Study of the retention and release of n-hexanal incorporated into soy protein isolate-lipid composite films. J. Food Eng. 2010, 100, 133-138. [CrossRef]

40. Hanani, Z.A.N.; Beatty, E.; Roos, Y.H.; Morris, M.A.; Kerry, J.P. Development and characterization of biodegradable composite films based on gelatin derived from beef, pork and fish sources. Foods 2013, 2, 1-17. [CrossRef]

41. Cao, N.; Fu, Y.; He, J. Preparation and physical properties of soy protein isolate and gelatin composite films. Food Hydrocoll. 2007, 21, 1153-1162. [CrossRef]

42. Muyonga, J.; Cole, C.; Duodu, K. Fourier transform infrared (FTIR) spectroscopic study of acid soluble collagen and gelatin from skins and bones of young and adult Nile perch (Latesniloticus). Food Chem. 2004, 86, 325-332. [CrossRef]

43. Gómez-Guillén, M.C.; Pérez-Mateos, M.; Gómez-Estaca, J.; López- Caballero, E.; Giménez, B.; Montero, P. Fish gelatin: A renewable material for developing active biodegradable films. Trends Food Sci. Technol. 2009, 20, 3-16. [CrossRef]

44. Moomand, K.; Lim, L.T. Oxidative stability of encapsulated fish oil in electrospun zein fibres. Food Res. Int. 2014, 62, 523-532. [CrossRef] 
45. Córdoba, L.J.P.; Sobral, P.J.A. Physical and antioxidant properties of films based on gelatin, gelatin-chitosan or gelatin-sodium caseinate blends loaded with nanoemulsified active compounds. J. Food Eng. 2017, 213, 47-53. [CrossRef]

46. Guillen, M.D.; Cabo, N. Usefulness of the frequency data of the fourier transform infrared spectra to evaluate the degree of oxidation of edible oils. J. Agric. Food. Chem. 1999, 47, 709-719. [CrossRef] [PubMed]

47. Hosseini, S.F.; Rezaei, M.; Zandi, M.; Farahmandghavi, F. Development of bioactive fish gelatin/chitosan nanoparticles composite films with antimicrobial properties. J. Food Chem. 2016, 194, 1266-1274. [CrossRef] [PubMed]

48. Souissi, N.; Abdelhedi, O.; Mbarek, A.; Kammoun, W.; Kchaou, H.; Nasri, M. Gelatin based bio-films prepared from grey triggerfish' skin influenced by enzymatic pretreatment. Int. J. Biol. Macromol. 2017, 105, 1384-1390. [CrossRef] [PubMed]

49. Abdelhedi, O.; Nasri, R.; Souissi, N.; Nasri, M.; Jridi, M. Sulfated polysaccharides from common smooth hound: Extraction and assessment of anti-ACE, antioxidant and antibacterial activities. Carbohydr. Polym. 2016, 152, 605-614. [CrossRef]

50. Tang, C.H.; Xiao, M.L.; Chen, Z.; Yang, X.Q.; Yin, S.W. Properties of cast films of vicilin-rich protein isolates from Phaseolus legumes: Influence of heat curing. LWT Food Sci. Technol. 2009, 42, 1659-1666. [CrossRef]

51. Akköse, A. Effect of Various Biopolymers on Glass Transition Temperature of Chicken Breast Meat. Akademik Gida 2018, 16, 120-126. [CrossRef]

52. Arfat, Y.A.; Ahmed, J.; Hiremath, N.; Auras, R.; Joseph, A. Thermo-mechanical, rheological, structural and antimicrobial properties of bionanocomposite films based on fish skin gelatin and silver-copper nanoparticles. Food Hydrocoll. 2017, 62, 191-202. [CrossRef]

53. Russo, R.; Malinconico, M.; Santagata, G. Effect of cross-linking with calcium ions on the physical properties of alginate films. Biomacromolecules 2007, 8, 3193-3197. [CrossRef]

54. Levine, H.; Slade, L. A polymer physicochemical approach to the study of commercial starch hydrolysis products (SHPs). Carbohydr. Polym. 1986, 6, 213-244. [CrossRef]

55. Jiang, Y.; Li, Y.; Chai, Z.; Leng, X. Study of the physical properties of whey protein isolate and gelatin composite films. J. Agric. Food. Chem. 2010, 58, 5100-5108. [CrossRef] [PubMed]

56. Pereda, M.; Aranguren, M.I.; Marcovich, N.E. Caseinate films modified with tung oil. Food Hydrocoll. 2010, 24, 800-808. [CrossRef]

57. Butnaru, E.; Stoleru, E.; Brebu, M.A.; Darie-Nita, R.N.; Bargan, A.; Vasile, C. Chitosan-Based Bionanocomposite Films Prepared by Emulsion Technique for Food Preservation. Materials 2019, 12, 373. [CrossRef]

58. Sarkar, A.; Ghosh, U. Natural antioxidants-The key to safe and sustainable life. Int. J. Latest Trends Eng. Tech. 2016, 6, 201.

59. Khantaphant, S.; Benjakul, S. Comparative study on the proteases from fish pyloric caeca and the use for production of gelatine hydrolysate with antioxidative activity. Comp. Biochem. Physiol. B Biochem. Mol. Biol. 2008, 151, 410-419. [CrossRef]

60. Bao, S.; Xu, S.; Wang, Z. Antioxidant activity and properties of gelatin films incorporated with tea polyphenol-loaded chitosan nanoparticles. J. Sci. Food Agr. 2009, 89, 2692-2700. [CrossRef]

61. Giménez, B.; Gómez-Estaca, J.; Alemán, A.; Gómez-Guillén, M.C.; Montero, M.P. Improvement of the antioxidant properties of squid skin gelatin films by the addition of hydrolysates from squid gelatin. Food Hydrocoll. 2009, 23, 1322-1327. [CrossRef]

62. Jouki, M.; Mortazavi, S.A.; Tabatabaee, F.; Koocheki, A. Characterization of antioxidant-antibacterial quince seed mucilage films containing thyme essential oil. Carbohydr. Polym. 2013, 99, 537-546. [CrossRef]

(C) 2019 by the authors. Licensee MDPI, Basel, Switzerland. This article is an open access article distributed under the terms and conditions of the Creative Commons Attribution (CC BY) license (http://creativecommons.org/licenses/by/4.0/). 